\title{
ARX AETERNAE DOMINATIONIS: \\ EMPEROR WORSHIP RITUALS IN THE \\ CONSTRUCTION OF A ROMAN \\ RELIGIOUS FRONTIER
}

\section{F. LOZANO}

Soon after the Roman conquest of Britannia, the colony of Camulodunum was founded and a magnificent temple in honor of the Emperor was built in the city. ${ }^{1}$ As a result of the inclusion of the island as a part of the Roman Empire, one of the most typical Roman religious practices started to take place, namely the imperial cult. ${ }^{2}$ This practice of emperor worship started in Rome after the divinization of Caesar, and must be included in the complex and long process of the accumulation of powers by the Emperors. ${ }^{3}$ As a matter of fact, after the reign of Augustus, the Emperors monopolized political appointments, together with the military force and, in general, all the powers which had

\footnotetext{
${ }^{1}$ For this cult see: D. Fishwick, The Imperial Cult in the Latin West Volume 1 (Leyden 1987-2005), part 1: $97 \mathrm{ff}$.; and C. Ando, Imperial Ideology and Provincial Loyalty in the Roman Empire (Berkeley 2000), 312-313.

${ }^{2}$ On emperor worship, see the classic works of: L. Cerfaux-J. Tondriau, Le culte des souverains dans la civilisation greco-romaine (Paris 1957); F. Taeger, Charisma. Studien zur Geschichte des antiken Herrscherkultes (Stuttgart 1957); A.D. Nock, 'Studies in the Graeco-Roman beliefs of the empire', Journal of Hellenic Studies 45 (1925), 84-101; and L.R. Taylor, The Divinity of the Roman Emperor (Middletown 1931). After the publication of these classic works, several studies shaped the topic as we understand it today: W. den Boer (ed.), Le Culte des Souverains dans l'Empire Romain (Geneve 1973); K. Hopkins, Conquerors and Slaves (Cambridge 1978), 197 ff.; S. Price, Rituals and Power. The Roman imperial cult in Asia Minor (Cambridge 1984); and Fishwick 1987-2005, op. cit. (n. 1). Of the vast number of recent works on imperial cult, I have found especially interesting: M. Bergmann, Die Strahlen der Herrscher. Theomorphes Herrscherbild und politische Symbolik im Hellenismus und der römischen Kaiserzeit (Mainz 1998); U.M. Liertz, Kult und Kaiser. Studien zu Kaiserkult und Kaiserverehrung in den germanischen Provinzen und in Gallia Belgica zur römischen Kaiserzeit (Rome 1998); M. Clauss, Kaiser und Gott. Herrscherkult im römischen Reich (Stuttgart-Leipzig 1999); R. Gordon, 'The Roman imperial cult and the question of power', in L. Golden (ed.), Raising the Eyebrow: John Onians and World Art Studies. An Album Amicorum in His Honour (Oxford 2001), 107 ff.; and I. Gradel, Emperor Worship and Roman Religion (Oxford 2002).

${ }^{3}$ On the beginning of this practice in Rome see: S. Weinstock, Divus Julius (Oxford 1971), especially chapter 17 .
} 
been traditionally distributed among the highest magistrates of the Roman Republic. ${ }^{4}$

These reforms, which could be labeled as "political", were accompanied by significant changes in traditional religion. Such changes were aimed at making room for the Emperor and its new government. The first Caesar was mainly responsible for the deep religious reform, usually called "Renaissance", which really meant a deep restructuring of the previous tradition, in which the rulers had concentrated progressively the highest religious positions, especially the position of Pontifex Maximus. ${ }^{5}$

As has already been said, the imperial cult is one of the most outstanding religious innovations of the Principate, of which the temple of Claudius at Camulodunum is just another example. Emperor worship strongly anchored in tradition became one of the ideological creations which promoted the social and political cohesion among the communities ruled by Rome. Furthermore, the rituals for the Caesars were the endorsement which the new figure of the absolute ruler needed. However, the imperial cult should not be seen as a monolithic and single entity, but as a complex phenomenon composed of a myriad of different cult practices. ${ }^{6}$ This diversity, among other reasons, is explained by the local association of the emperors with the main ancestral divinities of each community. ${ }^{7}$ While imperial cult was deeply rooted in local religion, at the same time it surpassed the local scale and served an imperial purpose as it "provided the context in which inhabitants of towns spread for hundreds of miles throughout the empire could celebrate their membership of a single political order and their own place within it".

Imperial cult was, then, a complex religious manifestation of both local and global signification and function. In this article I would like to $13 \mathrm{ff}$.

${ }^{4}$ J.A. Crook, 'Augustus: power, authority, achievement', CAH 10 (Cambridge $1996^{2}$ ),

${ }^{5}$ R. Gordon, 'The Veil of power: emperors, sacrificers, and benefactors', in M. BeardJ. North (eds.), Pagan Priests. Religion and Power in the Ancient World (London 1990), $199 \mathrm{ff}$.

${ }^{6}$ On the complexity of emperor worship see: P. Herz, 'Der römische Kaiser und der Kaiserkult: Gott oder primus inter pares?', in D. Zeller (ed.), Menschwerdung GottesVergöttlichung von Menschen (Freiburg 1988), 115 ff. See now also: F. Lozano, 'The creation of Imperial gods: Not only imposition versus spontaneity', in P.P. Iossif, A.D. Chankowski and C.C. Lorber (eds.), More than Men, Less than Gods. Studies in Royal Cult and Imperial Worship. Proceedings of the International Colloquium Organized by the Belgian School at Athens (1-2 November 2007) (Leuven-Paris 2011), 475-519.

7 F. Lozano, 'Divi Augusti and Theoi Sebastoi. Roman initiatives and Greek answers', The Classical Quarterly 57.1 (2007), $139 \mathrm{ff}$.

${ }^{8}$ Hopkins 1978, op. cit. (n. 2), 242. 
concentrate on the imperial importance of emperor worship, specifically in its constitution as a religious trait share by all people ruled by Rome. This role of the imperial cult as an integrator could be illustrated with many examples. However, I believe that this characteristic becomes even clearer if we take into consideration the hatred shown to the imperial cult by peoples that did not want to be integrated in the Empire. Going back to Britain's case, a clear proof of this is the animosity against Claudius' temple during the revolt of Boudica:

The bitterest animosity was felt against the veterans; who, fresh from their settlement in the colony of Camulodunum, were acting as though they had received a free gift of the entire country, driving the natives from their homes, ejecting them from their lands [...] More than this, the temple raised to the deified Claudius continually met the view, like the citadel of an eternal tyranny; while the priests, chosen for its service, were bound under the pretext of religion to pour out their fortunes like water $[\ldots] .^{9}$

The settlers died while defending the city and when "all else was pillaged or fired in the first onrush: only the temple, in which the troops had massed themselves, stood a two days' siege, and was then carried by storm". 10 Thus, Rome's enemies broke not only the Empire's political borders, but also their religious connection and the clearest sign of their subjugation, namely, the temple of Claudius and its symbolic and ritual context.

In this context of central, imperial-wide use of emperor worship, a special place was assigned to the ritual of sacrificing to the Emperor. It was a simple procedure to prove the submission to and acceptance of Rome and it was used to this end by Roman magistrates, generals, and provincials alike. It was also employed for the examination of enemies of the Roman state like the Christians. Sacrifice to the emperor was a performative act that affirmed the divine status of the emperor and stated the loyalty of his subdits. ${ }^{11}$

\footnotetext{
9 Tacitus, Annales 14.31.

10 Tacitus, Annales 14.32. On imperial cult in Britain see for convenience: M. Henig, Religion in Roman Britain (London 1984), 69-76; M. Millet, The Romanization of Britain. An Essay in Archaeological Interpretation (Cambridge 1990); and Fishwick 1987-2005, op. cit. (n. 1), I.1: $97 \mathrm{ff}$.

${ }^{11}$ On performative utterances (and acts) see the classic work by J.L. Austin, How to do things with words (Oxford 1962). See also: J. Derrida, Marges de la Philosophy (Paris 1972), 365 ff.; J. Derrida, Limited Inc (Evanston 1988). More recently: R.A. Rappaport, Ritual and Religion in the Making of Humanity (Cambridge 1999), $37 \mathrm{ff}$.
} 
This procedure was frequently used as an external mark to show the subjugation of foreign kings and peoples to Rome. This is the case, for instance, of the early foundation of imperial altars in Spain, ${ }^{12}$ to which we could add similar cultic constructions in Germany and France. ${ }^{13}$ Two examples from the East are even clearer. The first one took place at the time of Gaius. Artabanus, the king of Parthia, invaded Armenia in order to place his son Arsaces on his throne. In this manner, he could reach both territories of Upper Mesopotamia and Syria, while protecting his kingdom from Roman attacks. Tiberius did not react and, according to Tacitus, Artabanus was determined to regain the territories, which had once belonged to Persian and Macedonians. ${ }^{14}$ The governor Vitellius led the successful counteroffensive at the time of Gaius. The borders went back to its original position; Armenia became ruled by a pro-Roman king, and what it is even more interesting, when it comes to Artabanus:

He attended a conference with the Governor of Syria and, before returning across the river Euphrates, paid homage to the Roman Eagles and standards, and to the statues of the Caesars. ${ }^{15}$

During the reign of Nero and in the same scenario, the king Tiridates celebrated a similar ceremony:

It was then arranged that Tiridates should lay the emblem of his royalty before the statue of the emperor, to resume it only from the hand of Nero; and the dialogue was closed by a kiss. Then, after a few days' interval, came an impressive pageant on both sides: on the one hand, cavalry ranged in squadrons and carrying their national decorations; on the other, columns of legionaries standing amid a glitter of eagles and standards and effigies of gods which gave the scene some resemblance to a temple: in the centre,

12 On imperial cult in Hispania see for convenience: F. Lozano-J. Alvar, 'El culto imperial y su proyección en Hispania, in I. Rodà-J. Andreu-J. Cabrero (eds.), Hispaniae: Las provincias hispanas en el mundo romano (Barcelona 2009), $425 \mathrm{ff}$. For the altars and imperial cult in Northen Spain see: A. Tranoy, La Galice romaine. Recherches sur le nord-ouest de la péninsule ibérique dans l'Antiquité (Paris 1981); and J. Mangas, 'El culto imperial en el noroeste de Hispania', in T. Nogales-J. González (eds.), Culto imperial: política y poder (Mérida 2007), $705 \mathrm{ff}$. For similar constructions in Southern Spain: J. Beltrán-A.U. Stylow, 'Un aspecto del culto imperial en el suroeste bético: el "puteal” de Trigeros (Huelva), un altar dedicado a Augusto', in T. Nogales-J. González (eds.), Culto imperial: política y poder (Mérida 2007), $240 \mathrm{ff}$.

${ }_{13}$ Fishwick 1987-2005, op. cit. (n. 1), III. 1: 6 ff.

14 Tacitus, Annales 6.31. See: S.P. Mattern, Rome and the Enemy, Imperial Strategy in the Principate (London 1999), 175. On Roman frontiers and the army, see also: A.K. Goldsworthy, The Roman Army at War 100 BC-AD 200 (Oxford 1996); and B. Isaac, The Limits of Empire: The Roman Army in the East (Oxford 1990).

15 Suetonius, Gaius 14.3. See also: Cassius Dio 59.27.2-3. 
the tribunal sustained a curule chair, and the chair a statue of Nero. To this Tiridates advanced, and, after the usual sacrifice of victims, lifted the diadem from his head and placed it at the feet of the image. ${ }^{16}$

The same importance was granted to the Emperor in the religion of the Roman army. ${ }^{17}$ The Caesars were worshiped in the sanctuary that dominated every Legionary camp, together with the eagles and other military symbols. Likewise, the Emperors' statues were main elements on every Legion and thus, they were venerated. Furthermore, the troops were submitted to a strict religious regime, which made their community life revolve around Roman official gods, which had to be worshiped. The military calendar found at Dura Europos ${ }^{18}$ clearly shows the continuous presence of rituals for the divi; to an extend that it can be assessed that the official religion of the soldiers was mainly devoted to the performance of festivals and sacrifices whose main purpose was to celebrate the Empire and to religiously help the endurance of the emperor and its regime. ${ }^{19}$ This was, without a doubt, an external expression of the troops' faithfulness.

16 Tacitus, Annales 15.29.

17 Much has been written about the religion of the Roman army. See for instance: E. Birley, 'The religion of the Roman Army: 1895-1977', ANRW II 16.2 (1978), 1506; and J. Helgeland, 'Roman Army religion', ANRW II 16.2 (1978), 1470 ff. See lately the general account in O. Stoll, 'The religions of the armies', in P. Erdkamp, A companion to the Roman Army (London 2008), $451 \mathrm{ff}$. On the religion of the Roman army in the East see: O. Stoll, Zwischen Integration und Abgrenzung; die Religion des Römischen Heeres in Nahen Osten (St. Katharinen 2001). See also recently: L. de Blois-E. Lo Cascio (eds.), The Impact of the Roman Army (200 BC-AD 476): Economic, Social, Political, Religious and Cultural Aspects (Leyden 2007). On the relation between the Caesars and the army, see: J.B. Campbell, The emperor and the Roman army, 31 BC-AD 235 (Oxford 1984).

18 On the calendar see: R.O. Fink-A.S. Hoey-W.F. Snyder, 'The Feriale Duranum, Yale Classical Studies 7 (1940), $1 \mathrm{ff}$. Challenging the traditional view on the calendar: M.B. Reeves, The Feriale Duranum, Roman Military Religion, and Dura-Europos: A Reassessment, (Diss. State University of New York at Buffalo). On religion in DuraEuropos see: T. Kaizer, 'Language and religion in Dura-Europos', in H.M. CottonR.G. Hoyland-J.J. Price-D.J. Wasserstein (eds.), From Hellenism to Islam Cultural and Linguistic Change in the Roman Near East (Cambridge 2009), 235 ff.; and T. Kaizer, 'Patterns of worship in Dura-Europos: a case study of religious life in the Classical Levant outside the main cult centres', in C. Bonnet-V. Pirenne-Delforge-D. Praet, Les religions orientales dans le monde grec et romain cent ans après Cumont (1906-2006) Bilan historique et historiographique (Brussels-Rome 2009), $153 \mathrm{ff}$.

19 I leave to one side in this paper the question of the level of interaction that existed between local communities and the army. Some scholars refer to the army as a total institution, isolated from surrounding societies, see for instance: B. Shaw, 'Soldiers and society: the army in Numidia', Opus 21 (1983), $144 \mathrm{ff}$. who is criticising the opinion of E. Fentress, Numidia and the roman army (Oxford 1979). Contrary to Shaw's argument: 
In a similar way, the Flavian municipal law stated that town magistrates must sacrifice and swear openly "in an assembly by Jupiter, the divine Augustus, the divine Claudius, the divine Vespasian Augustus, the divine Titus Augustus, the genius of Imperator Caesar Domitian Augustus and the dei Penates" that they would act in accordance with the law and in the best interest of the town. And this local sacrifice to the emperor went hand in hand with a provincial sacrifice usually presided over by the governor. ${ }^{20}$

Likewise, the relations between Christians and the imperial power prove this use of the sacrifices to the Emperor. I do not intend to give a new answer to the old question of "why were Christians persecuted?", but to show that one of the most frequent methods of examination of accused Christians was the realization of sacrifices to the emperors. ${ }^{21} \mathrm{To}$ sustain my case, I would like to highlight one of the best examples of how provincial rulers fought against Christians during the Roman Principate, that is the famous letter of Pliny to Trajan and the subsequent answer from the Emperor. ${ }^{22}$ The Latin author informed the emperor about the presence of Christian groups in his province, Bithynia. At the beginning, wrote Pliny, "this is the line I have taken with all persons brought before me on the charge of being Christians. I have asked them in person if they are Christians, and if they admit it, I repeat the question a second and third time, with a warning of the punishment awaiting them. If they persist, I order them to be led away for execution; for, whatever the

R. Alston, Soldier and Society in Roman Egypt: A social history (London 1995), chap. 7. See also on this topic: N. Pollard, Soldier, cities and civilians in Roman Syria (London 2001); and N. Pollard, 'The Roman army as "total institution" in the Near East? Dura-Europos as a case study' in D. Kennedy (ed.), The roman army in the East (Ann Arbor 1996), $211 \mathrm{ff}$.

${ }^{20}$ ILS 6087 par. 64. See: A. Bendlin, 'Peripheral centres-central peripheries: religious communication in the Roman Empire', in H. Cancik-J. Rüpke (eds.), Römische Reichsreligion und Provinzialreligion (Tübingen 1997), $35 \mathrm{ff}$.

${ }^{21}$ This was the topic of a very interesting intellectual dispute between Sherwin-White and G.E.M. de Ste. Croix published in Past and Present 26 (1963) and 27 (1964). The problem was also addressed by F. Millar, 'The imperial cult and the persecutions', in den Boer 1973, op. cit. (n. 2), 145 ff. Against Millar's opinion, see: H.S. Versnel, "Geef de keizer wat des keizers is en Gode wat Gods is. Een essay over een utopisch conflict", Lampas 21 (1988), $233 \mathrm{ff}$. Of the overwhelming recent bibliography on Christian persecutions, I found especially interesting: J.B. Rives, 'The decree of Decius and the religion of Empire', Journal of Roman Studies 89 (1999), 135 ff.; S.J. Friesen, Imperial Cults and the Apocalypse of John. Reading Revelation in the Ruins (Oxford 2001); and H.J de Jonge, 'The apocalyse of John and the Imperial Cult', in H.F.J. Horstmanshoff-H.W. Singor-F.T. van StratenJ.H.M. Strubbe (eds.), Kykeon. Studies in Honour of H.S. Versnel (Leyden 2002), $127 \mathrm{ff}$.

${ }^{22}$ For the letters see: A.N. Sherwin-White, The Letters of Pliny. A Historical and Social Commentary (Oxford 1966). 
nature of their admission, I am convinced that their stubbornness and unshakeable obstinacy ought not to go unpunished".23

After Pliny's involment in this matter the accusations increased and so he deviced a method of examination: "I considered that I should dismiss any who denied that they were or ever had been Christians when they had repeated after me a formula of invocation to the gods and had made offerings of wine and incense to your statue (which I had ordered to be brought into court for this purpose along with the images of the gods), and furthermore had reviled the name of Christ". ${ }^{4}$ Therefore, when the Roman governor was forced to find an easy way to separate the loyal subjects from the rebel ones, he used sacrifice to the emperor as the key tool of examination.

Governors were in charge of judging non-citizens from the province. The place where those reunions took place was presided over by the Emperor's statues. Therefore, it is not much to suppose that when a Christian or any enemy of the regime was taken before the governor, he could be asked to worship the Emperor at that same moment. The iconography shows some interesting examples of this. Among them, the Christian representation on sarcophagi from the second to the fourth century of the three brothers who denied to worship the king Nebuchadnezzar stands out. S. Price has convincingly linked this scene to Christian prosecution, because instead of the king the image represented is that of the Emperor's bust placed behind a Roman magistrate. ${ }^{25}$ Tertullian explains the reason for their denial as follows:

For it is for this reason, too, that the famous example of the three brothers precedes us, who, though in other respects obedient to the king Nebuchadnezzar refused with the utmost firmness to do homage to his image, thus showing that everything must be regarded as idolatry which elevates someone beyond the measure of human honour unto the likeness of divine majesty. ${ }^{26}$

In conclusion, the appearance of the Principate as a political system made it necessary to create a new ideological base, better adapted to the needs of the new government and the new political and social reality.

${ }^{23}$ Plinius Minor, Epistulae 10.96.

${ }^{24}$ Plinius Minor, Epistulae 10.96.

${ }^{25}$ For these sarcophagi see: F.W. Deichmann, Repertorium der christliche-antiken Sarkophage (Wiesbaden 1967), I.no.: 324; 338; 339; 351; 596; 718. For a parallel in the catacombs at Rome consult: J. Wilpert, Die Malereien der katakomben Roms (Freiburg 1903), pls. 13 and 78. See also Price 1984, op. cit. (n. 2), 220 ff.

26 Tertulianus, De idololatria 15.9. 
This ideological construction, which was supported by the State, but which actually benefited a significant part of the population submitted to Rome, was not universally accepted, as I have tried to show in this paper. Moreover, this opposition was greater, mainly since imperial cult, and specifically the sacrifice to the emperor, soon became one of the main tools to prove adherence to Rome; a means to separate Roman from nonRoman and enemy from friend.

Seville, May 2009 